\title{
Monocyte/macrophages promote vasculogenesis in choroidal neovascularization in mice by stimulating SDF-1 expression in $\mathrm{RPE}$ cells
}

\author{
Yuan-yuan Shi • Yu-sheng Wang • Zhao-xia Zhang • \\ Yan Cai • Jing Zhou • Hui-yuan Hou • Nico van Rooijen
}

Received: 8 November 2010 /Revised: 27 March 2011 /Accepted: 10 April 2011 /Published online: 8 June 2011

(C) Springer-Verlag 2011

\begin{abstract}
Background Monocyte-macrophages play important roles in choroidal neovascularization (CNV); however, the mechanism is unclear. This study investigated the effects of monocyte depletion on laser-induced $\mathrm{CNV}$ in mice, especially the involvement of bone marrow-derived cells (BMCs) and underlying molecular mechanisms.

Methods Clodronate-liposomes (lip) were used to deplete monocytes and their effect on retinal pigmental epithelium (RPE) cells, endothelial cells, and BMCs was analyzed. Green
\end{abstract}

This work was supported by grants from National Natural Science Foundation of China (No.30371516, 30672291) and National Basic Research Program of China (973 Program / 2011CB510200). We have full control of all primary data, and agree to allow Graefe's Archive for Clinical and Experimental Ophthalmology to review our data upon request.

Electronic supplementary material The online version of this article (doi:10.1007/s00417-011-1699-4) contains supplementary material, which is available to authorized users.

Y.-y. Shi $\cdot$ Y.-s. Wang $(\bowtie) \cdot$ Y. Cai $\cdot$ H.-y. Hou

Department of Ophthalmology, Eye Institute of Chinese PLA,

Xijing Hospital, Fourth Military Medical University,

15 West Changle road,

Xi'an 710032 Shaanxi Province, China

e-mail: wangys@fmmu.edu.cn

\section{Z.-x. Zhang}

Department of Ophthalmology,

1st Hospital of Shanxi Medical University,

Shanxi, People's Republic of China

\section{J. Zhou}

Department of Pedodontics, School of Stomatology,

Fourth Military Medical University, Xi'an,

Shaanxi 710032, People's Republic of China

N. van Rooijen

Department of Cell Biology and Immunology, Vrije Universiteit,

Amsterdam, Netherlands fluorescent protein (GFP)-chimeric mice were developed by transplanting bone marrow cells from GFP transgenic mice to $\mathrm{C} 57 \mathrm{BL} / 6 \mathrm{~J}$ mice. $\mathrm{CNV}$ was induced by laser photocoagulation. Chimeric mice were intravenously treated with clodronate-lip, PBS-lip or PBS, 1 day before and after lasering. Histopathological and choroidal flatmount analysis were performed to measure $\mathrm{CNV}$ severity and BMCs recruitment. BMCs expression of endothelial cell marker CD31 and vascular smooth muscle cell marker $\alpha$-SMA in CNV were detected by immunofluorescence. Expression of stromal cell-derived factor-1 (SDF-1) protein in vivo was detected by immunofluorescence as well as ELISA assay. SDF-1 was also examined by RT-PCR and ELISA in a human monocytes-RPE cells co-culturing system.

Results No valid evidence for the toxicity of clodronate-lip was found. Depletion led to significant inhibition of CNV and BMCs recruitment into laser spots on days 3 and 14 , reduced BMC expression of CD31 and $\alpha$-SMA on day 14 , and decreased expression of SDF-1 in vivo on day 3. SDF1 was mostly within and around the RPE cells in the laser lesion. SDF-1 was dramatically up-regulated in RPE cells after co-culturing with monocytes.

Conclusions Monocytes may promote experimental CNV, especially BMC contribution in mice, by promoting SDF-1 production in RPE cells.

Keywords Choroidal neovascularization - Monocyte/ macrophages - Retinal pigment epithelium - Bone marrow derived cells $\cdot$ Stromal cell-drived factor $\cdot$ Vascular endothelial growth factor 1

\section{Introduction}

Choroidal neovascularization (CNV) is a common pathological endpoint for a variety of chorioretinal diseases. 
CNV causes $90 \%$ of all vision loss in age-related macular degeneration (AMD), which is the most common cause of blindness in the elderly in developed countries $[1,2]$. As life expectancy increases and the global population ages, $\mathrm{CNV}$, especially secondary to $\mathrm{AMD}$, is increasing as a socio-medical problem.

The molecular and cellular mechanisms underlying CNV are not fully elucidated. Recently, evidence has suggested the importance of immune system activation and inflammation, particularly macrophages, in wet AMD, which is characterized by $\mathrm{CNV}$ [3-6]. Macrophages are present in at least $50 \%$ of $\mathrm{CNV}$ specimens, and may participate in all stages of CNV [7]. Macrophages could modulate CNV severity. Administration of interleukin-1 (IL-1) [8], tumor necrosis factor- $\alpha$ (TNF- $\alpha)$ [9], IL-6 inhibitors [10], and some antioxidant [11] and lipid-lowering drugs [12] suppresses murine $\mathrm{CNV}$ and causes less macrophage infiltration. Genetic ablation of the receptor for monocyte chemotactic protein-1 (MCP-1) inhibits CNV in mice [13]. Depletion of macrophages with dichloromethylene diphosphonate (clodronate)-liposomes (clodronate-lip) reduces the size and leakage of laser-induced CNV [14, 15]. However, all in all, these studies mostly focused on the effects of whole CNV severity and cell amounts without looking into the detail, and thus leaving the mechanism unsolved.

Previous studies have shown that in addition to cells in situ, a lot of bone marrow-derived cells (BMCs) are recruited into $\mathrm{CNV}$ and differentiated into endothelial cells (ECs) and vascular smooth muscle cells (VSMCs), which indicates that in addition to angiogenesis, vasculogenesis also plays an important role in $\mathrm{CNV}$ development. It was reported that about $45 \%$ cells in laser-induced CNV was bone marrow derived. Meanwhile, BMCs also modulate the severity of CNV [1618]. During this process, it is well-known that stromal cellderived factor-1 (SDF-1) is involved in recruiting BMCs and also promoting $\mathrm{CNV}$ development [19]. We wondered whether monocyte/macrophage depletion would affect BMC recruitment that contributes to the $\mathrm{CNV}$ attenuation; in other words, whether the roles of monocyte-macrophages in $\mathrm{CNV}$ development might be mediated, in part, by modulating vasculogenesis, and if this was true, whether SDF-1 would be involved in it. In this experiment, we used laser-induced $\mathrm{CNV}$ in $\mathrm{C} 57 \mathrm{BL} / 6 \mathrm{~A}$ mice transplanted with bone marrow cells from green fluorescent protein (GFP)-transgenic mice to observe $\mathrm{CNV}$ progression, especially vasculogenesis following monocytes-macrophage depletion. To detect the mechanism, we also developed a model of monocyte-retinal pigmental epithelium (RPE) cells co-culture in vitro to survey the alteration of SDF-1. In addition, as clodronate-lip was suspected to inhibit experimental $\mathrm{CNV}$ by damaging local cells in the laser lesion [20], we firstly evaluated the effects of clodronate-lip before going into the present research.

\section{Materials and methods}

Animals

Mice were handled in accordance with the ARVO Statement for the Use of Animals in Ophthalmic and Vision Research. Female, wild-type 8-week-old C57BL/6 J mice (Experimental Animal Center, The Fourth Military Medical University) were divided randomly into three groups, and the right eyes were used. Age-matched female GFP+/+ transgenic mice (C57BL/6 background, Institute of Neurosciences, The Fourth Military Medical University) were used for bone marrow transplantation.

Clodronate-liposome and PBS liposome preparation and efficacy evaluation

Monocyte/macrophages were depleted by apoptosis induction with clodronate-lip. Clodronate-lip and phosphate-buffered saline (PBS)-liposomes (PBS-lip) were prepared as previously described [21]. Briefly, $8 \mathrm{mg}$ cholesterol (Sigma-Aldrich, St. Louis, MO, USA) and $86 \mathrm{mg}$ phosphatidylcholine (Lipoid EPC; Lipoid, Ludwigshafen, Germany) were dispersed in $10 \mathrm{ml}$ of $0.6 \mathrm{M}$ clodronate solution (a gift of Roche Diagnostics GmbH, Mannheim, Germany) and sonicated gently. The suspension was centrifuged, and clodronate-lip or PBS-lip were then resuspended in sterile PBS. The final clodronate-lip suspension contained $5 \mathrm{mg}$ of clodronate per $\mathrm{ml}$. PBS-lip was prepared under the same conditions, with PBS instead of the clodronate solution.

To confirm depletion of monocyte-macrophages by clodronate-lip, mice were given $0.2 \mathrm{ml}$ clodronate-lip intravenously, and after 2 days, anesthetized and perfused transcardially with $20 \mathrm{ml} 0.9 \%$ saline, then $50 \mathrm{ml} 4 \%$ paraformaldehyde. Spleens were harvested and dehydrated in a graded alcohol series, embedded in paraffin, and sectioned at $3 \mu \mathrm{m}$. Immunohistochemistry for monocytemacrophages in spleen was performed by deparaffinizing, and microwaving in $0.01 \mathrm{~mol} / 1$ sodium citrate buffer $(\mathrm{pH} 6$, $10 \mathrm{~min}, 95-100^{\circ} \mathrm{C}$ ) for antigen retrieval, then incubating in $3 \% \mathrm{H}_{2} \mathrm{O}_{2}$ for $30 \mathrm{~min}$ at room temperature (RT). After blocking with $5 \%$ bovine serum albumin (Sigma-Aldrich, St. Louis, MO, USA) and 5\% normal goat serum (Zhongshan Biotechnologie Company, Beijing, China) in PBS for $30 \mathrm{~min}$, sections were incubated overnight at $4{ }^{\circ} \mathrm{C}$ with rat-anti mouse $\mathrm{F} 4 / 80$ primary antibodies (1:400; Serotec, Raleigh, NC, USA), then biotinylated goat antirat second antibody (1:200; Zhongshan Biotechnologie Company, Beijing, China) for $30 \mathrm{~min}$ at $37^{\circ} \mathrm{C}$, and streptavidin-horseradish peroxidase at $37^{\circ} \mathrm{C}$ for $30 \mathrm{~min}$. A 3-amino-9-ethylearbazole substrate kit (Zhongshan Biotechnologie Company, Beijing, China) was used at RT for staining, with counterstaining with hematoxylin. GVA 
mounting solution (Zhongshan Biotechnologie Company, Beijing, China) was applied to mount coverslips.

Tracing liposomes and assessment of clodronate toxicity

To assess if clodronate-lip was toxic to eyes after lasering in vivo, we traced liposomes in mice by labeling PBS-lip with 3,3'-dioctadecyloxacarbocyanine perchlorate (DiO). Briefly, $2.2 \mathrm{mg} \mathrm{DiO}$ (Beyotime Institute of Technology, China) were added to $1 \mathrm{ml} 100 \%$ ethanol and sonicated in a waterbath at $50 \mathrm{kHz}$ for $1 \mathrm{~min}$. Then $10 \mu \mathrm{DiO}$ solution was added to $1 \mathrm{ml}$ PBS-lip. The mixture was shaken and incubated at RT for $10 \mathrm{~min}$ in dark. After two washes at $20,000 \times \mathrm{g}$ for $10 \mathrm{~min}$, the supernatant was removed and sterile PBS was added to restore the original volume. After resuspension, the mixture was kept in dark at $4^{\circ} \mathrm{C}$. Labeling was confirmed by fluorescence and light microscopy (BX51, Olympus, Tokyo, Japan). Four C57 mice were injected with lip-DiO intravenously 1 day before and after lasering, and sacrificed at day 3 . Then choroidal flatmounts and frozen sections of posterior eye were prepared as described below. Flatmounts were then directly observed under laser scanning confocal microscopy (Fluoview 1000; Olympus, Tokyo, Japan), and frozen sections were immunostained for macrophage markers F4/80 (1:400; Serotec, Raleigh, NC, USA), endothelial cell marker CD31 (1:150, Chemicon, Temecula, CA, USA), and RPE cell marker cytokeratin (1:100; Santa Cruz Biotech, Santa Cruz, CA, USA), followed by Texas red or tetraethyl rhodamine isothiocyanate (TRITC)-conjugated second antibody (1:200 Abcam, Cambridge, MA, USA or 1:150, Jackson, West Grove, PA, USA). Finally, sections were counterstained with 40, 6-diamino-2- phenylindole (DAPI; Molecular Probes, Eugene, OR, USA) and observed under laser scanning confocal microscopy.

Effects of clodronate-lip on proliferation and angiogenic function of RPE and ECs were also tested. Human RPE (hRPE) cells were cultured as previously described, in accordance with the Helsinki agreement [22]. Fetal rhesus choroid-retinal endothelial cells $(\mathrm{RF} / 6 \mathrm{~A})$ cells were from the Shanghai Institute for Biological Sciences. RPE were plated at $1 \times 10^{4}$ cells $/ \mathrm{ml}$, while $\mathrm{RF} / 6 \mathrm{~A}$ were plated at $2 \times 10^{4}$ cells/ $\mathrm{ml}$ in 96-well plates in $200 \mu \mathrm{l}$ DMEM with $10 \%$ fetal bovine serum (FBS, Hangzhou Sijiqing Biological Engineering Materials Co., Ltd. China), and allowed to adhere overnight before $20 \mu$ l clodronate-lip or PBS-lip was added. Cell proliferation was measured by 3-(4,5-dimethylthiazol-2-yl)2,5-diphenyl tetrazolium bromide (MTT)assay at 24 and $48 \mathrm{~h}$. Briefly, $20 \mu \mathrm{l}$ MTT was added in each well after removing media, and incubated for $4 \mathrm{~h}$. Formazan crystals were dissolved in $150 \mu \mathrm{l}$ dimethyl sulfoxide, and optical density was read at $570 \mathrm{~nm}$ and $450 \mathrm{~nm}$. To evaluate whether clodronate-lip would affect angiogenic function of RPE cells,
VEGF and SDF- $1 \alpha$ expression in RPE cells after being cultured with clodronate-lip or PBS-lip was tested by enzyme-linked immunosorbent assays (ELISA).

In addition, we also tested the effect of clodronate-lip on the BMCs, which is a heterogeneous cell population comprised of multiple types of stem/progenitor cells and is reported to be incorporated into the CNV by differentiation into ECs and SMCs using the well-established plastic-adherent methods [23]. Briefly, bone marrow cells from tibias and femurs of 4week-old female C57BL/6 mice were cultured on plastic dishes in Dulbecco's modified Eagle's medium supplemented with $15 \%$ fetal calf serum (Gibco, Grand Island, NY, USA) and incubated at $37^{\circ} \mathrm{C}$ with $5 \% \mathrm{CO}_{2}$ in an incubator. After 3 days, nonadherent cells were removed by washing with phosphate-buffered saline, and the remaining monolayer cells were cultured in fresh medium until they reached confluence. After 6-7 days, cells were trypsinized $(0.25 \%$ trypsin with $0.1 \%$ EDTA). Then the cells of primary culture were plated at $5 \times 10^{3}$ cells $/ \mathrm{ml}$ in 96 -well plates, and then the MTT assay was performed at $24 \mathrm{~h}$ and $48 \mathrm{~h}$ as described above, and optical density was read at $492 \mathrm{~nm}$.

Bone marrow transplantation and analysis of chimerism

Chimeric mice were generated by bone marrow transplantation and qualified by chimerism analysis as previously described [24]. Briefly, unpurified bone marrow cells from GFPtransgenic mice were injected into tail veins of irradiated wild-type C57BL/ $6 \mathrm{~J}$ mice $\left(2 \times 10^{6}\right.$ per mouse). After 4 weeks, peripheral blood was analyzed by fluorescence activated cell sorter (FACS) scan to determine the degree of chimerism.

\section{Induction of CNV and administration of clodronate-lip} and PBS-lip

Laser photocoagulation was performed on the right eyes of qualified chimeric mice or C57BL/6 J mice using a $532 \mathrm{~nm}$ laser (Iris Radiation Systems, USA; spot size $75 \mu \mathrm{m}$, power $100 \mathrm{mw}$, duration $0.1 \mathrm{~s}$ ) through a contact lens. Six laser spots were applied between the major retinal vessels 1.5-2 disc diameters from the optical disc. Disruption of Bruch's membrane was confirmed when a cavitation bubble appeared without hemorrhage. For systemic depletion of macrophages, chimeric mice received $0.2 \mathrm{ml}$ of cloronatelip (clodronate mice) intravenously 1 day before and after the laser procedure. Control mice received PBS-lip (PBSlip mice) or PBS (PBS mice) at the same time points.

Measurement of lesion severity

Histopathological analysis was performed as described previously [24]. Mice were killed 2 weeks after lasering ( $n=4$ per group). Prepared paraffin sections of eye cups 
were processed with hematoxylin and eosin $(\mathrm{H} \& \mathrm{E})$, and CNV thickness was measured as described below.

Choroidal flatmount was performed on day 14 after $\mathrm{CNV}$ induction ( $n=4 \mathrm{mice} /$ group/time point) as described previously [25]. Anesthetized mice were perfused transcardially with $0.9 \%$ saline followed by $4 \%$ paraformaldehyde. Eye globes were enucleated and then the anterior segment and the neural retina were removed. The remained RPE-choroid-sclera complex was flatmounted with six radial cuts or more, and then permeabilized in $0.2 \%$ Triton X-100 for $24 \mathrm{~h}$, before transferring into $1: 1,000$ rhodamineconjugated Ricinus communis agglutinin (Vector Laboratories, Burlingame, CA, USA) for $24 \mathrm{~h}$, followed by washing in $0.01 \mathrm{M}$ Tris-buffered saline Tween-20 (TBST) for $24 \mathrm{~h}$. Flatmounts were examined and photographed by confocal laser scanning microscopy, and CNV area was assessed as described in image analysis section.

\section{Analysis of BMC recruitment and differentiation}

Flatmounts made from the three groups of mice on days 3 and 14 were analyzed for BMC recruitment. Serial crosssections of eyes were also prepared to calculate the number of BMCs in the lesion. Briefly, on days 3 and 14 the clodronate- and PBS-lip mice ( $n=4$ mice/group/time point) were perfused transcardially after lasering as described above. The right eyes were removed and post-fixed in $4 \%$ paraformaldehyde for $2 \mathrm{~h}$ at $4^{\circ} \mathrm{C}$. After cryoprotection in $30 \%$ sucrose in $0.1 \mathrm{M}$ phosphate buffer overnight at $4^{\circ} \mathrm{C}$, vertical sections were cut on a cryostat $(12 \mu \mathrm{m}$; RM31; Leica, Heidelberger, Nussloch, Germany) and mounted on gelatin-coated slides. For sections from day 14, endothelial and vascular smooth muscle cells (VSMCs) derived from BMCs in CNV were identified by immunofluorescence, performed as described [20]. Serial cross sections were incubated with primary antibodies against CD31 (1:500), $\alpha$-SMA (1:600; Neomarkers, Fremont, CA, USA), Texas Red or TRITC-conjugated secondary antibodies, and finally counterstained with DAPI. Slides were coverslipped with anti-fading medium, and examined with the confocal laser scanning microscope as described in image analysis section. In addition, to determine whether decreased BMCs in the lesions were more than or just the blood-derived macrophages, frozen sections from chimeric mice were immunostained for macrophage markers F4/80 (1:400; Serotec, Raleigh, NC, USA) to assess the ratio of F4/80 positive BMCs, which indicated blood-derived macrophages to total BMCs on days 3 and 14 .

SDF-1 protein expression in the eye

The amount of SDF-1 protein expression in clodronate and PBS-lip mice on day 3 after lasering was determined by immunofluorescence in sections and also ELISA assay. To detect SDF-1 expression in the lesion, serial cross-sections of eyes ( $n=4$ per group) were incubated with primary antibody of SDF-1(1:150, Santa Cruz, CA, USA). After being incubated with TRITC-conjugated secondary antibody and counterstained with DAPI, sections were analyzed under the laser scanning confocal microscope. SDF-1 levels in eyes ( $n=4$ per group) were determined by using a mouse SDF-1 ELISA kit (USCN Life Science and Technology).At day 3, eyes were removed and prepared for ELISAs as previously reported [23]. Eyes were quickfrozen in $100 \mu$ l of phosphate-buffered saline ( $\mathrm{pH}$ 7.4) with $0.05 \%$ phenylmethylsulfonyl fluoride and homogenized manually on ice, followed by three freeze-thaw cycles on liquid nitrogen and wet ice. The homogenates were centrifuged in a refrigerated desktop centrifuge to pellet the insoluble material, and the supernatants were collected. ELISAs were performed following the manufacturer's instructions.

To search for the main contributor of SDF-1, immunofluorescence for RPE cells and SDF-1 was performed simultaneously in the sections from mild C57/BL mice on day 3, based on the fact that RPE cells have been considered as the main source of SDF-1 in human CNV [26]. Sections were incubated with primary antibodies against pan-cytokeratin (CK) $(1: 150$, Santa Cruz, CA, USA), SDF-1 (1:150, Santa Cruz, CA, USA), and then TRITC and FITC-conjugated secondary antibodies, and finally counterstained with DAPI, examined under the confocal laser scanning microscope. The relationship of SDF-1 and RPE cell positions was assessed.

Image analysis

H\&E-stained sections were digitized with a color video camera connected to a light microscope. Flurorescence images were captured by Fluoview 1000 (Olympus, Tokyo, Japan). Images were analyzed by Image Pro Plus software. Morphometric data for lesions were averaged per eye. Data of each group were calculated and expressed as mean \pm standard deviation (SD).

To measure CNV thickness, consecutive H\&E sections were examined to select intact CNV. CNV thickness was then measured vertically from the adjacent RPE layer to the top of the $\mathrm{CNV}$ and expressed in $\mu \mathrm{m}$. A single $\mathrm{CNV}$ thickness was represented by the maximum data of all of its consecutive sections. For measuring CNV surface area, the agglutinin-positive red area at the laser spots in the flatmounts was measured and expressed in $\mu \mathrm{m}^{2}$.

For assessing BMC recruitment and incorporation into the laser spot at days 3 and 14, GFP positive cell areas in each laser lesion in the flatmounts were measured and expressed in $\mu \mathrm{m}^{2}$. Comparisons were between averages of 
groups. To assess constituent ratios of BMCs in the lesion, nuclei overlapped with or without GFP were counted respectively in the laser spots in the sections of posterior eyes. To assess constituent ratio of macrophages, the number of F4/80-positive BMC cells was counted and divided by the total number of BMCs in the lesion of wildtype mice on days 3 and 14 after lasering. For BMC differentiation, green fluorescence surrounded by red fluorescence was considered to be differentiated BMCs. Only cells with a DAPI-labeled nucleus were included. For detecting macrophages, ECs, and RPE cells for toxicity assessment, red (TRITC) membranes surrounding a clearly blue (DAPI) nucleus were considered to be positive. For assessing SDF-1 protein expression at laser spots, TRITC fluorescence intensity (FI) was determined and averaged.

\section{Monocyte isolation}

Human monocytes were freshly isolated from the peripheral blood of healthy volunteers as previously described [27], in accordance with the Helsinki agreement. Briefly, peripheral blood was drawn into a heparinized syringe and diluted 1:1 in $0.9 \%$ saline. Mononuclear cells were separated by density gradient centrifugation using lymphocyte separation medium (LOTS1077, Tianjin Haoyang Biological Technology). Cells were washed and layered onto a slightly hyperosmolar Percoll gradient (density $=1.064 \mathrm{~g} / \mathrm{ml}$ ) for the enrichment of monocytes. Percoll solutions were made as follows. First, an isosmotic Percoll was prepared by mixing one volume $\mathrm{NaCl} 1.5 \mathrm{M}$ with nine volumes of Percoll (Pharmacia, density $=1.130 \mathrm{~g} / \mathrm{ml}$ ). The Percoll gradient was made by mixing 1:1 (v/v) isosmotic Percoll with PBS/Citrate $\left(\mathrm{NaH}_{2} \mathrm{PO} 41.49 \mathrm{mM} ; \mathrm{Na}_{2} \mathrm{HPO} 49.15 \mathrm{mM} ; \mathrm{NaCl}\right.$ $139.97 \mathrm{mM} ; \mathrm{C}_{6} \mathrm{H}_{5} \mathrm{Na}_{3} \mathrm{O}_{7} .2 \mathrm{H}_{2} \mathrm{O} 13 \mathrm{mM} ; \mathrm{pH}$ 7.2). Cells were incubated with CD14 antibody (eBioscience, San Diego, CA, USA) and analyzed by flow cytometry to assess the purity.

Cell culture and RPE-monocyte co-culture

HRPE cells were used at cell passages 4 to 6 . For hRPE cell and monocyte co-culture [28, 29], $2 \times 10^{5} \mathrm{hRPE}$ were plated in 6-well plates and incubated overnight in DMEM containing 10\% FBS without antibiotics. Freshly enriched monocyte populations at $4 \times 10^{5}$ were directly overlaid onto hRPE cells. Non-contact co-culturing was performed by implanting monocytes in Millicell (Millipore, Bedford, MA, USA), separating monocytes from hRPE with porous polycarbonate filters. After incubating for 4 or $24 \mathrm{~h}$, conditioned media were harvested and centrifuged at $1000 \mathrm{x} \mathrm{g}$ for $10 \mathrm{~min}$, and stored at $-80^{\circ} \mathrm{C}$ for ELISA. To determine protein sources, hRPE cells and monocytes were harvested respectively after co-culturing for $4 \mathrm{~h}$ and being separated by being incubated with cold $\mathrm{Ca}^{2+}$ - and $\mathrm{Mg}^{2+}$ - free PBS containing $5 \mathrm{mM}$ EDTA for 3 min. PCR was used to detect mRNA.

ELISA assay of SDF- $1 \alpha$ in vitro

SDF- $1 \alpha$ concentrations were quantified with a sandwich ELISA kit (R\&D Systems, Minneapolis, MN, USA and Beijing 4A Biotech, Beijing, China), according to the manufacturer's protocol. Standards were $0.5-\log$ protein dilutions from $200 \mathrm{pg}$ to $3.125 \mathrm{ng} /$ well. The minimum amount of detectable chemokines was $0.8 \mathrm{pg} / \mathrm{ml}$ for SDF- $1 \alpha$.

\section{RT-PCR}

RNA was extracted with Trizol (Invitrogen, Carlsbad, CA, USA) and converted to cDNA with a RevertAid First Strand cDNA Synthesis Kit (Fermentas, Burlington, ON, Canada). The amplification program was $95^{\circ} \mathrm{C}$ for $10 \mathrm{~min}$, followed by $95^{\circ} \mathrm{C}$ for $10 \mathrm{~s}$, and $60^{\circ} \mathrm{C}$ for $30 \mathrm{~s}$, for 40 cycles. Primers for RPE cells were GAPDH sense, $5^{\prime}$-GCG CTG AGT ACG TCG TGG AG-3'; GAPDH antisense, 5'-CAG TTG GTG GTG CAG GAG G-3'; SDF-1 sense, 5'-GAT TGT AGC CCG GCT GAA GA-3; SDF-1 antisense, 5'TTC GGG TCA ATG CAC ACT TGT-3. After amplification, samples were run on a $1.5 \%$ agarose gel (Sigma, Poole, UK) in TBE (0.045 M Tris-borate, 0.001 M EDTA) containing $0.4 \mathrm{mg} / \mathrm{ml}$ ethidium bromide, and bands were photographed on a UV transilluminator. Relative abundance of product was assessed as the ratio of the aimed gene band to the GAPDH band for each sample, using Kodak Digital Science 1D software.

\section{Statistical analysis}

Data from quantitative assays are expressed as mean $\pm \mathrm{SD}$. One-way ANOVA analysis was used for statistical analysis for CNV thickness and area on day 14, and GFP cells area on days 3 and 14. Independent samples $t$-test was used for the others. SPSS software 11.0 (SPSS Inc., Chicago, USA) was used. Results at $P<0.05$ were considered statistically significant.

\section{Results}

Assessment of efficiency and toxicity of clodronate-lip

Spleen sections of clodronate-lip-treated mice showed few macrophages, while many macrophages were found in the spleens of PBS-lip-administered mice (Fig. 1a, b), confirming the efficacy of clodronate-lip treatment. All liposomes were green by fluorescent microscopy, implying 100\% labeling (Fig. 1c). After intravenous injection into mice, liposome$\mathrm{DiO}$ was detected at laser spots in the choroidal flatmounts 

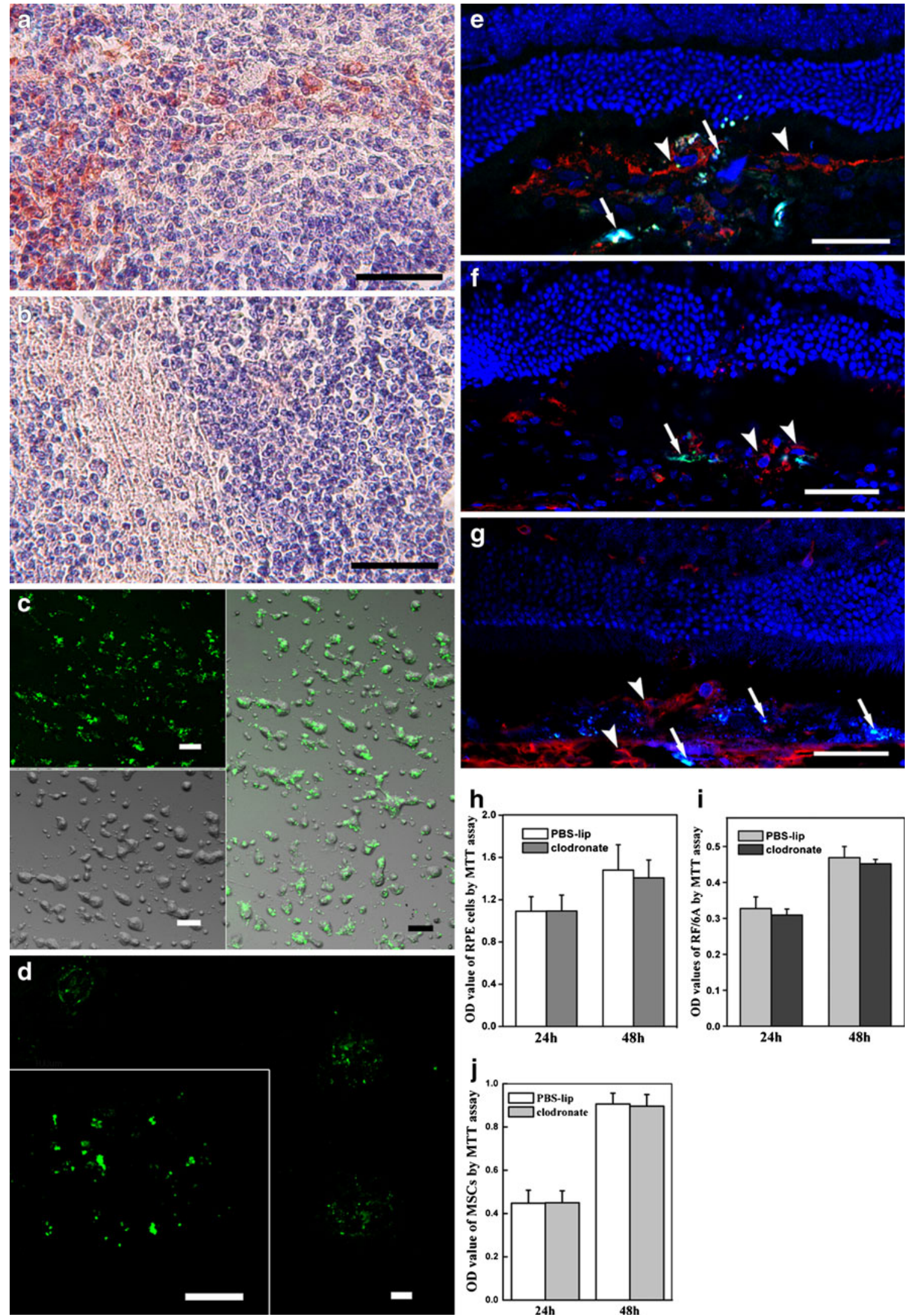
4Fig. 1 Assessment of efficiency and toxicity of clodronate-liposomes. Immunostaining for $\mathrm{F} 4 / 80$ shows macrophages (red) in spleen sections of PBS-liposome (lip) mice (a) and almost no positives in clodronate mice (b). PBS-lip was investigated under fluorescence (upper insert) and light microscope (lower insert), and the merged figure indicated $100 \%$ labeling (c). After tail injection, DiO labeled liposome (green) appeared in flatmounts within the laser lesion (d). Liposomes (green, arrow in $\mathbf{e}, \mathbf{f}, \mathbf{g}$ ) were phagocytosed by macrophages (arrowhead, e) in the laser lesion at day 3, but not by retinal pigmental epithelium (RPE) cells (arrowhead, f) or endothelial cells (arrowhead, $\mathbf{g}$ ). The nucleus was counterstained by DAPI (blue). Bar $=50 \mu \mathrm{m}$. MTT assay showed similar optical density (OD) values for RPE cells cultured with PBS-lip and clodronate-lip (h), and also the OD value for RF/6A (i), and BMCs $(\mathbf{j})(n=3, P>0.05)$

3 days after lasering (Fig. 1d). Labeled liposomes could also be detected in the laser lesion in cross sections. By immunofluorescence, liposomes were found adjacent to, or enclosed by macrophages (Fig. 1e), and not enclosed by RPE cells or ECs (Fig. 1f, g). In vitro, there were no significant difference in OD values revealed by MTT assay between RPE cells cultured with PBS-lip or clodronate-lip at 24 and $48 \mathrm{~h}(P>0.05$, Fig. 1h). Situation was similar for RF/6A cells $(P>0.05$, Fig. 1i) and also the BMCs $(P>0.05$, Fig. 1j), indicating that compared with PBS-lip, clodronate-lip was no more harmful to RPE or endothelial cell proliferation. VEGF protein level in the supernatant of RPE cells cultured with clodronate-lip was similar to that of PBS-lip-treated cells $(1108.94 \pm 176.58$ vs $998.1 \pm 126.94 \mathrm{pg} / \mathrm{ml}, P>0.05)$, while SDF-1 $\alpha$ was not detected in the supernatant of RPE cells cultured neither with PBS-lip nor clodronate-lip.

\section{Generation of chimeric mice}

Four weeks after bone marrow transplantation, the survival rate of mice transplanted with exogenous bone marrow was $100 \%$. The mean percentage of circulating karyocytes identified as transplanted cells by GFP expression was $91.45 \% \pm 2.22 \%$, indicating the success of the bone marrow transplantation.

Reduction in CNV severity and recruitment of BMCs into the lesion

After monocyte depletion, $\mathrm{CNV}$ development and recruitment of BMCs were investigated on days 3 and 14 to assess effects of monocyte deprivation. In choroidal flatmounts, $\mathrm{CNV}$ area of the clodronate group was markedly smaller than that of the PBS and PBS-lip groups on day $14(4713.89 \pm 1537.72$ vs $9240.05 \pm 1971.41$ vs $9596.35 \pm 2120.70 \mu^{2}, P<0.05$, Fig. 2a, b, g). In the cross section, CNV thickness of the clodronate group was thinner than that of the PBS and PBSlip groups $(23.57 \pm 2.31$ vs $30.61 \pm 1.65$ vs $29.21 \pm 1.82 \mu \mathrm{m}$, $P<0.05$, Fig. $2 \mathrm{c}, \mathrm{d}, \mathrm{h})$, while there was no significant difference in $\mathrm{CNV}$ area and thickness between the two control groups. GFP-positive cells were detected within the laser spots on days 3 (Fig. 2e, f) and 14 (Fig. 2a, b) in the flatmounts. Clodronate mice demonstrated smaller GFPpositive cells areas on both day 14 and day 3, while the PBS and PBS-lip groups were similar to each other (236.62 \pm 74.71 vs $2606.24 \pm 460.61$ vs $2651.58 \pm 500.5 \mu \mathrm{m}^{2}$ for day $14, P<0.05$, Fig. 2I; $190.99 \pm 60.45$ vs $2699.61 \pm$ 550.8 vs $2753.82 \pm 596.96 \mu^{2}$ for day $3, P<0.05$, Fig. 2 j). Then, cell number was further counted in the laser spots in cross-sections. The number of GFP-positive cells was found decreased in clodronate mice on days $3(3.1 \pm 1.45$ vs $18.58 \pm$ 4.27, $P<0.05)$ and $14(1.6 \pm 1.35$ vs $20.57 \pm 3.15, P<0.05)$, while the number of non-GFP-positive cells, representing the resident cells, was similar to the PBS-lip group on day 3 $(8.44 \pm 3.00$ vs $9.55 \pm 2.46, P>0.05)$, but was less than PBSlip mice on day $14(8.3 \pm 3.34$ vs $20.57 \pm 4.20, P<0.05)$. Then, using these numbers to calculate the constituent ratio of GFP-positive cells to total number showed that the ratio of BMCs decreased from $66.1 \%$ (PBS-lip group) to $26.9 \%$ (clodronate group) on day 3, and from 50\% (PBS-lip group) to $16.2 \%$ (clodronate group) on day 14 . However, many GFP-positive cells remained beneath the lesions in clodronate mice, similar to the PBS-lip mice. Furthermore, GFPpositive cells that differentiated into ECs and VSMCs were rare in clodronate mice (Fig. 3a, c), while differentiated BMCs were easily found in PBS-lip mice (Fig. 3b, d). In addition, we found that approximately $30 \%$ of BMCs were F4/80 positive on day 3 , and $10 \%$ on day 14 .

\section{SDF-1 expression}

Local SDF-1 protein expression in the lesions on day 3 was investigated to determine the potential mechanism of the monocyte depletion effects. Cross-sections indicated that local SDF-1 protein expression was dramatically decreased after monocyte depletion (Fig. 4a, b), and this was confirmed by fluorescent intensity measurements $\left[(7.0 \pm 5.0) \times 10^{4}\right.$ vs $(86.8 \pm$ $\left.\left.21.1) \times 10^{4} \mathrm{FI}, P<0.01\right)\right]$ and ELISA assay $(578.5 \pm 54.9$ vs $1603.2 \pm 86.2 \mathrm{pg} /$ eye, $P<0.01)$. SDF-1 was mainly expressed in or adjacent to RPE cells (Fig. 4c).

SDF-1 mRNA and protein expression were tested in a co-culture system, with monocyte purity greater than $90 \%$. SDF- $1 \alpha$ protein was undetectable at 4 or $24 \mathrm{~h}$ in RPE cells cultured alone. Contact co-culture of RPE and monocytes significantly stimulated expression of SDF- $1 \alpha$ to detectable levels. SDF- $1 \alpha$ in the supernatant from contact co-cultures of monocytes and RPE cells was higher than in the Millicell at 4 and $24 \mathrm{~h}(583.74 \pm 57.86 \mathrm{vs} 187.67 \pm 21.61 \mathrm{pg} / \mathrm{ml}$ for $4 \mathrm{~h}, P<0.01 ; 934.08 \pm 19.83$ vs $263.36 \pm 48.04$ for $24 \mathrm{~h}, P<$ 0.01 , Fig. 5a). This indicated that contact with monocytes was crucial, and potently stimulated SDF- $1 \alpha$ protein production. SDF-1 mRNA levels were low in RPE cells cultured alone, and in monocytes co-cultured with RPE 

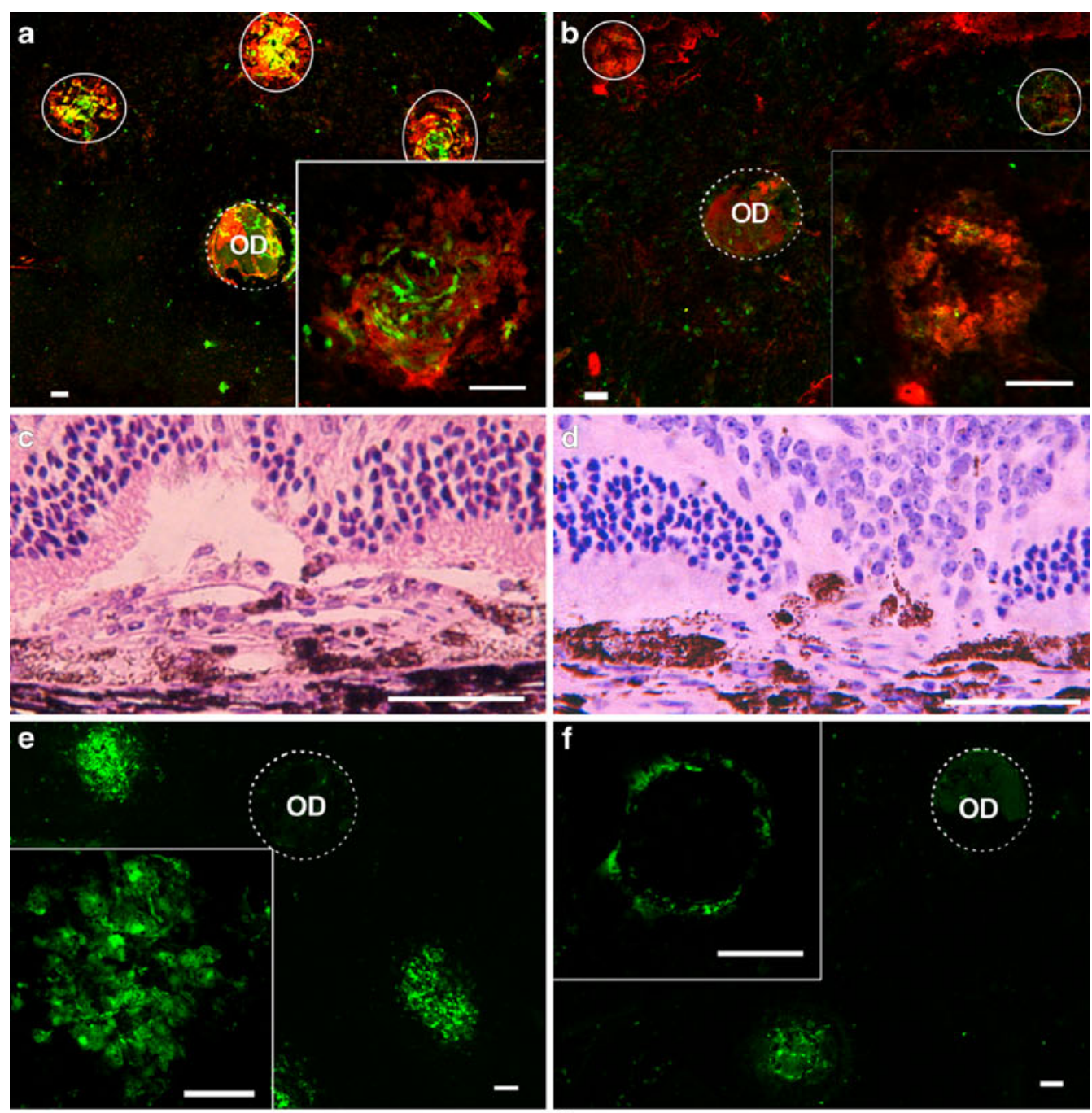

g

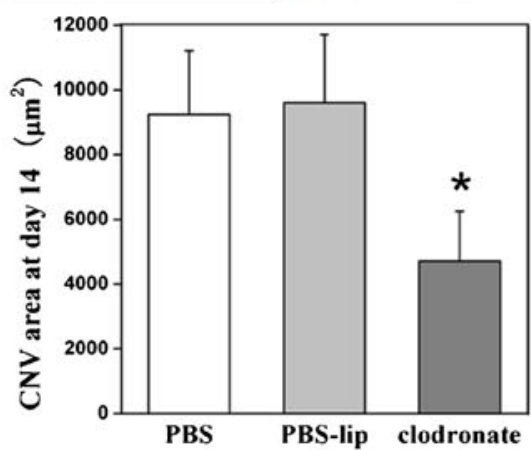

i

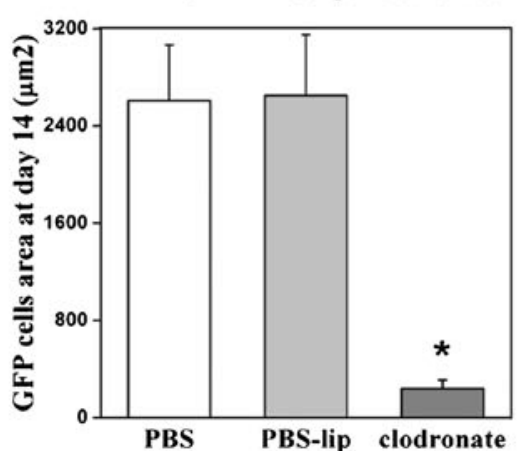

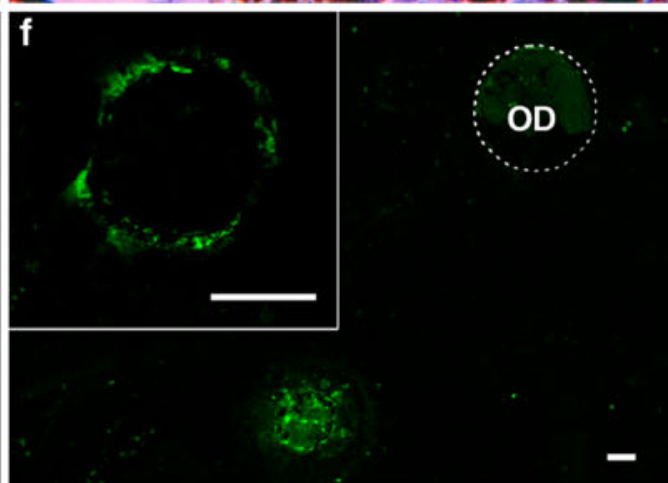

h

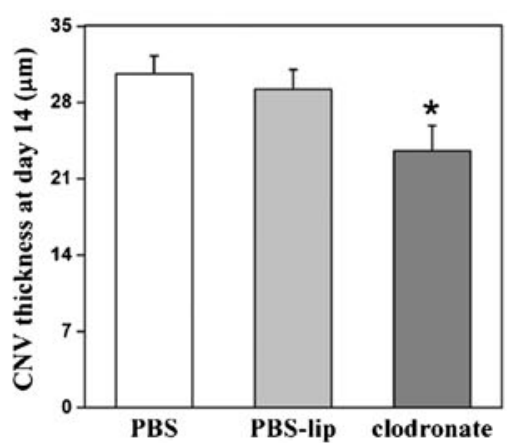

j

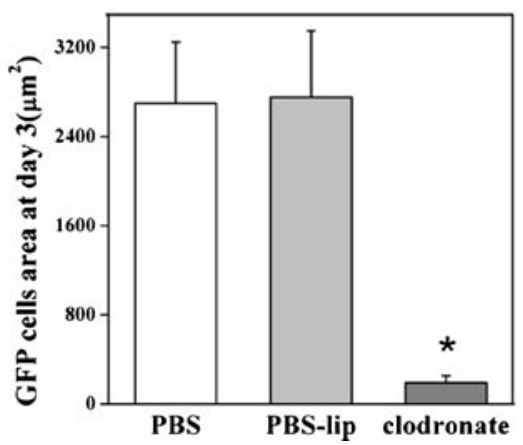


4 Fig. 2 Morphometry of choroidal neovascularization (CNV) and recruitment of bone marrow derived cells (BMCs) into lesions. On day $14, \mathrm{CNV}$ (solid line) formed around the optical disc (dotted line), as represented in choroidal flatmounts (a, b). Compared with PBSliposome (lip) mice (a), clodronate mice (b) showed smaller CNV areas and decreased green fluorescent protein (GFP) positive cell (indicating BMCs) recruitment (green or yellow cells from red overlap). Insert: amplified figure of a single CNV. Cross sections of control mice [c showed larger and thicker CNV compared with clodronate mice (d)]. Choroidal flatmounts at day 3 showed more BMCs (green) at the lesion in control mice (e) than in clodronate mice (f). Bar $=50 \mu \mathrm{m}$. Statistical analysis showed clodronate mice demonstrated smaller CNV thickness $(23.57 \pm 2.31$ vs $30.61 \pm 1.65$ vs $29.21 \pm$ $1.82 \mu \mathrm{m}, P<0.05, \mathrm{i}), \mathrm{CNV}$ area $(4713.89 \pm 1537.72$ vs $9240.05 \pm$ 1971.41 vs $\left.9596.35 \pm 2120.70 \mu^{2}, P<0.05, \mathrm{~h}\right)$ and BMC area $\left(236.62 \pm 74.71\right.$ vs $2606.24 \pm 460.61$ vs $2651.58 \pm 500.5 \mu^{2}$ for day $14, P<0.05$, I; $190.99 \pm 60.45$ vs $2699.61 \pm 550.8$ vs $2753.82 \pm$ $596.96 \mu \mathrm{m}^{2}$ for day $3, P<0.05$, j). ( ${ }^{*} P<0.05$ vs PBS, PBS-lip mice). Data for the two control groups were similar $(P>0.05)$

cells, but SDF-1 mRNA levels were obviously elevated in RPE cells after co-incubation with monocytes (Fig. 5b).

\section{Discussion}

Monocytes have long been closely linked to adult angiogenesis including tissue repair, remodeling, or tumors. Abolishment of monocytes drastically reduces angiogenesis. Specific chemoattraction of monocytes highly amplifies angiogenesis [30-32]. Similarly, several experiments have confirmed
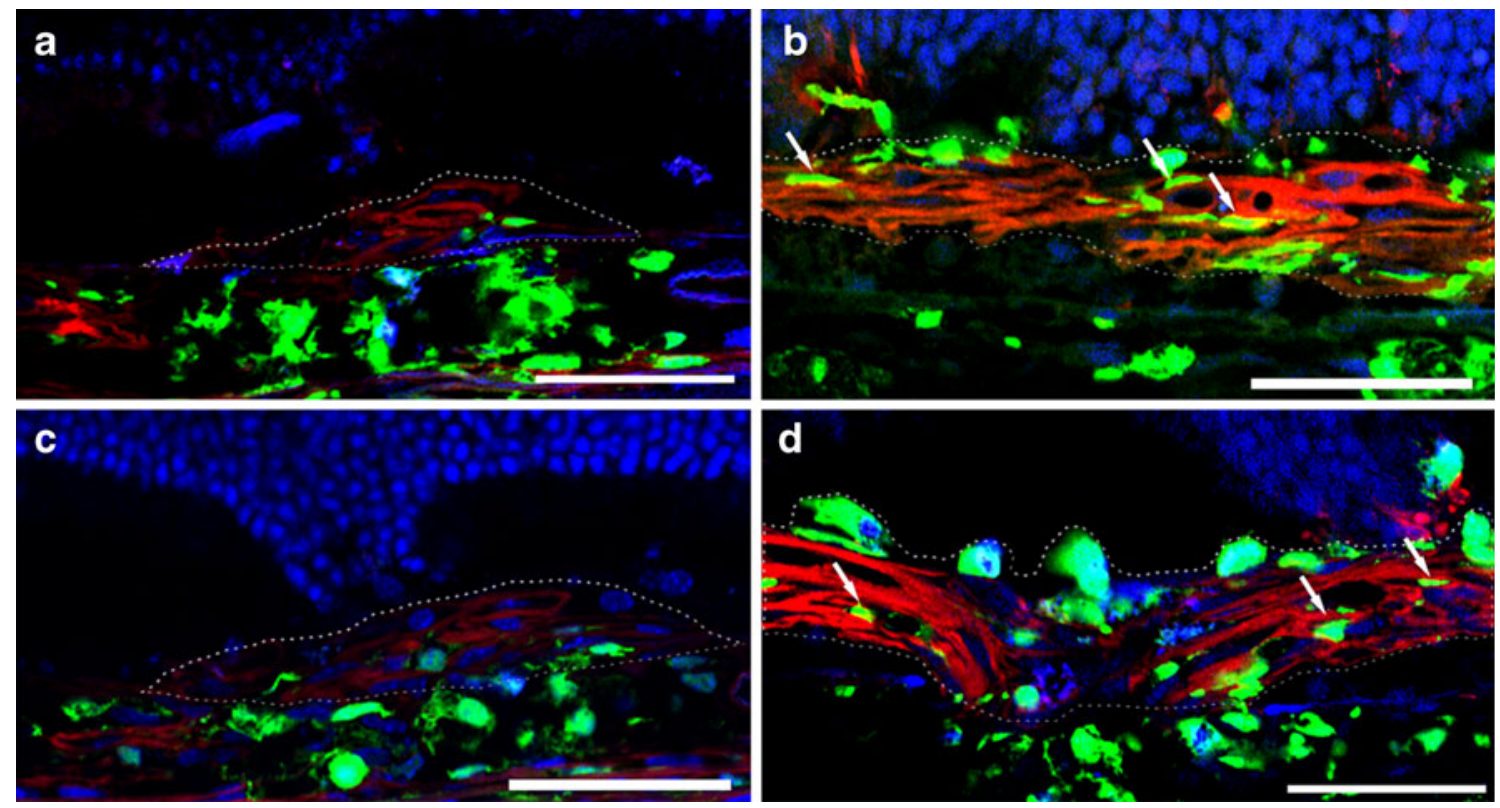

Fig. 3 Incorporation of bone marrow derived cells (BMCs) and differentiation in choroidal neovascularization (CNV) on day 14. Clodronate mice $(\mathbf{a}, \mathbf{c})$ demonstrated smaller $\mathrm{CNV}$ (dotted line) and very few BMCs (green) compared with controls (b, d). Almost no BMCs differentiated to endothelial cells $(\mathrm{EC}, \mathrm{red})(\mathbf{a})$ or vascular monocyte-macrophages also modulate CNV severity, as reviewed above. However, the potential mechanism of the modulation remains unclear. In this study, we made efforts to survey the effect of monocyte absence on vasculogenesis, which has recently been considered as one of the important contributors to $\mathrm{CNV}$ development. We also tried to investigate the mechanisms of the effects, in vivo and in vitro.

To deplete monocytes, we used clodronate-lip, which has recently been widely used in animal experiments for evaluating angiogenesis effects [14, 15] (see more at www.clodronate liposomes.org). This drug is selectively ingested by macrophages, inducing apoptosis without affecting any other cells. The number of macrophages in peripheral blood and tissues is markedly decreased by this drug, and the effects last for 24-48 h. It is believed to be a safe and stable method for monocyte-macrophage depletion [33]. However, it has been argued that choroidal endothelial cells may be susceptible to clodronate-lip, because liposomes may leak into the laser lesions [34]. In our study, it was true that liposome-DiO could be seen in the laser lesions on day 3, while none were encapsulated by ECs or RPE cells. In addition, clodronate-lip did not inhibit proliferation or VEGF, SDF-1 $\alpha$ production of RPE or RF/6A cells compared to PBS-lip, suggesting a lack of toxicity against endothelial and RPE cells, since VEGF and SDF-1 are both potent angiogenic factors in the neovascularization process. In addition, considering that BMCs are also the main constituent cells in laser spots, we further tested the effects of clodronate-lip on its proliferation

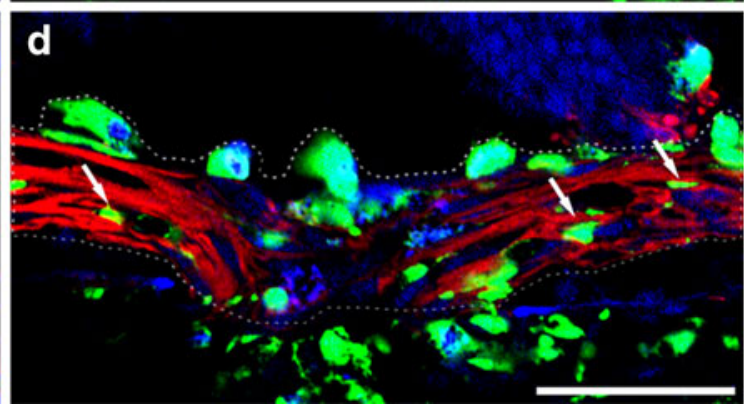

smooth muscle cells (VSMCs, red) (c) in clodronate mice. While more EC (red), VSMCs (red), and BMCs (green) were seen in control mice, and among them some BMCs differentiated into EC (b) or VSMCs (d) (arrow), many BMCs (green) were also observed beneath the CNV in both clodoronate and control mice. Bar $=50 \mu \mathrm{m}$ 

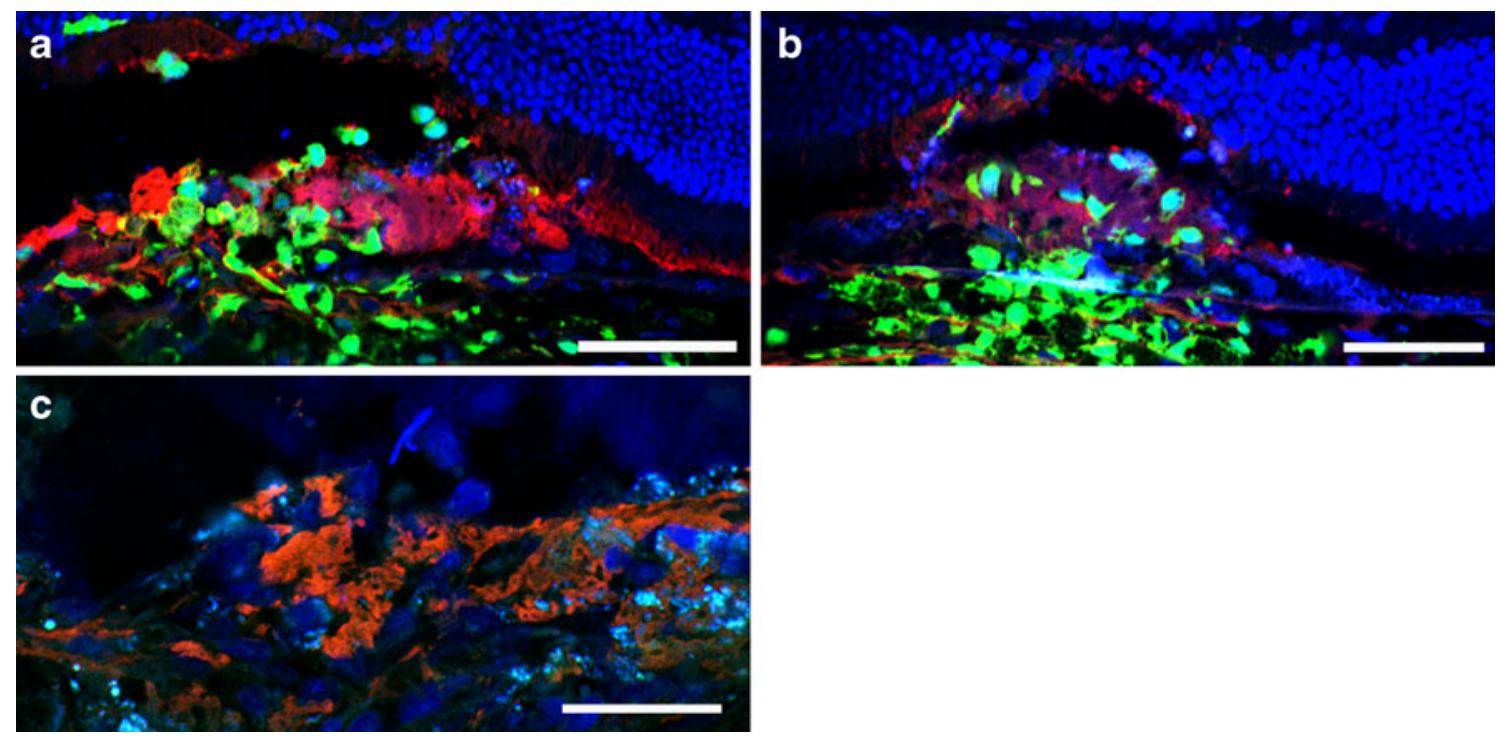

Fig. 4 Expression of stromal cell-derived factor-1 (SDF-1) on day 3. There were many bone marrow derived cells (BMCs, green) in the laser lesion with high expression of SDF-1 (red) in control mice (a),

in vitro, yet still no apparent negative affect was observed. But more extensive investigation, such as ultrastructure examination, might be needed to completely rule out the toxicity of clodronate-lip in the future.

We confirmed that monocyte depletion dramatically decreased the area of $\mathrm{CNV}$, which was consistent with the previous reports $[14,15]$. Meanwhile, significantly fewer BMCs were recruited into laser spots on days 3 and 14, as demonstrated by choroidal flatmounts. As there were no significant differences between the PBS-lip and PBS groups, we then cut down the two control groups to only one, and thus focused our comparison on clodronate and PBS-lip mice.

Consistently, in posterior eye sections, significantly fewer BMCs and reduced ratio of BMCs were detected at the laser spots in monocyte-depleted mice. However, by counting cell nuclei, the resident cell number was nearly the same between monocyte-depleted mice and controls on day 3. This implied that monocyte depletion mainly affected BMC recruitment, rather than resident cells, at this early stage. However, someone may argue that depleting monocytes would certainly diminish BMCs, because monocytes in CNV are mostly blood-derived, and originally released from the bone marrow $[35,36]$. Therefore, we further calculated the number of macrophages, and found that approximately $30 \%$ of BMCs were $\mathrm{F} 4 / 80$ positive on day 3 , and about $10 \%$ on day 14 . Since actually more than $80-90 \%$ of BMCs were undetectable after monocyte depletion, we thus confirmed that in addition to monocyte-macrophages, other BMCs were indeed diminished on days 3 and 14. Further, very few BMCs were embedded in the CNV membrane on day 14 and almost no BMCs differentiated into ECs or VSMCs after monocyte depletion,

while clodronate mice had got few BMCs (green) and low protein expression (red) (b). Bar $=50 \mu \mathrm{m}$. The SDF-1 (green) were mostly expressed adjacent or within the RPE cells (red) (c). Bar $=10 \mu \mathrm{m}$

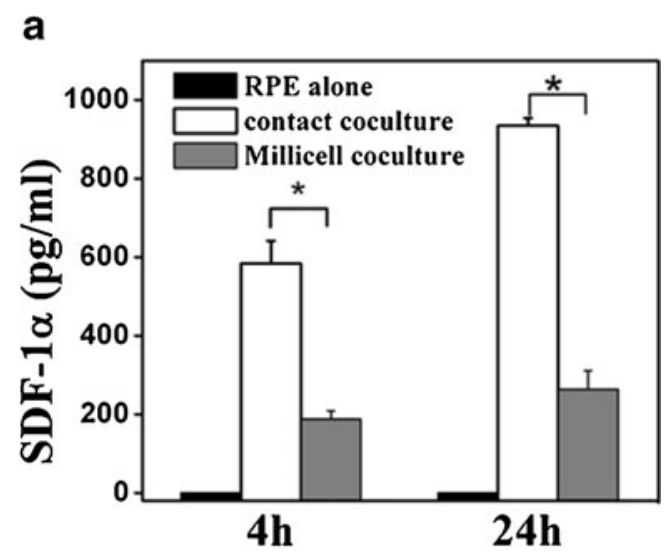

b
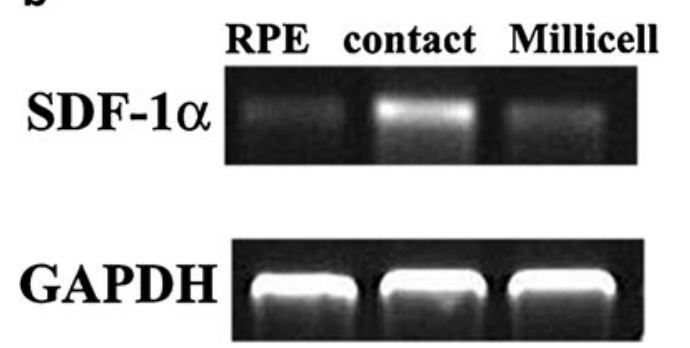

Fig. 5 Stromal cell-derived factor-1 (SDF-1) mRNA and protein expression in the co-culture system. As shown in the statistical analysis (a), SDF-1 $\alpha$ was dramatically enhanced after contact with monocytes at $4 \mathrm{~h}$ and $24 \mathrm{~h}$, and was greater than in the Millicell system $(583.74 \pm 57.86 \mathrm{vs} 187.67 \pm 21.61 \mathrm{pg} / \mathrm{ml}$ for $4 \mathrm{~h} ; 934.08 \pm 19.83$ vs $263.36 \pm 48.04$ for $24 \mathrm{~h}, n=4, * P<0.01$ vs millicell co-culture ); PCR showed SDF-1 mRNA could be detected in retinal pigmental epithelium (RPE) cells after contact with monocytes, but not in RPE cells cultured alone or in the Millicell system (b) 
indicating lower incorporation of BMCs in the vessels in mature CNV. Interestingly, in spite of fewer BMCs in CNV on days 3 and 14, many BMCs were also found in the choroid beneath the $\mathrm{CNV}$ membrane. We then examined the local SDF-1 expression, trying to unveil the mechanism.

We, for the first time, demonstrated a decrease in SDF-1 after monocyte depletion. The decreased SDF-1 expression in laser spots and in the whole eye on day 3 might explain the reduced recruitment of BMCs in CNV. SDF-1 facilitates the migration and homing of BMCs, and promotes firm adhesion of BMCs to the vessel endothelium by increasing the expression of vascular cell adhesion molecule on the EC. SDF-1 increases the permeability of ECs, facilitating the migration of BMCs [37, 38]. Recently, the retention of marrow-derived circulating cells in close proximity to angiogenic vessels has been reported to be mediated by SDF-1 [39]. Based on this information, we hypothesized that although decreased, SDF-1 levels in the lesions of monocytedepleted mice were still higher than the surrounding cells, which resulted in the recruitment of many BMCs to the choroid beneath $\mathrm{CNV}$, but failed to cause BMC migration out of choroidal vessels into the subretinal space, or to maintain them for $\mathrm{CNV}$ formation by differentiating into vessel constituents such as ECs and VSMCs. So why did SDF-1 decrease? Interestingly, we noticed that in an ischemia model, monocyte depletion did not affect local levels of SDF-1 after femoral artery excision, which excluded monocytes as the SDF-1 generator [40]. This suggested another contributor of SDF-1 that is affected by monocyte depletion during $\mathrm{CNV}$ formation.

Using the immunofluorescence method, we found that SDF-1 protein was mostly expressed at or around the RPE layer, which indicated RPE cells as the main contributor of SDF-1 in the lesions. A previous experiment also has implied that RPE cells may be the most important source of SDF-1 in human CNV [26]. RPE cells are sensitive to inflammatory agents and monocyte interaction [41]. Monocyte extravasation and cell-cell contact between monocytemacrophages and RPE cells are sequential events during AMD [42]. Macrophages are found adjacent to RPE in experimental CNV [43]. Therefore, we assumed that it was interaction of monocyte-macrophages and RPE cells promoting SDF-1. We thus performed in vitro monocyte-RPE co-culturing, and found that SDF-1 secretion was largely promoted by direct contact with monocytes, while SDF-1 in RPE cells cultured alone was undetectable by ELISA, similar to results reported by Isabel et al., who found that SDF- $1 \alpha$ production by RPE cells could be detected by ELISA, but only at levels near the detection limit $(1.33 \pm$ $1.0 \mathrm{pg} / \mathrm{ml}$ ) [44]. We also showed that direct contact with monocytes was significantly more potent for stimulating SDF-1 production in the supernatant than indirect contact through a polyporous membrane. To tell the exact resource of enhanced SDF-1 protein, we next examined SDF-1 mRNA by PCR. It showed that RPE cells cultured alone also constitutively expressed SDF-1 mRNA, but very weakly. After co-culturing, SDF-1 mRNA expression was up-regulated in RPE cells, while expression in monocytes was very low. This indicated that the enhanced protein was mostly from RPE cells, and thus demonstrated that contact with monocyte could considerably stimulate SDF-1 production in RPE. So after laser induction, monocyte infiltration would stimulate SDF-1 in the lesion.

In addition, a positive cycle for promoting vasculogenesis could be expected when monocytes infiltrated laser spots. SDF-1 is able to recruit monocytes [39, 45, 46]. Preincubation of monocytes with SDF-1 enhances adhesion to activated human umbilical vein endothelial cells [47]. Bone marrow derived stromal cells are capable of producing large amounts of VEGF, basic fibroblast growth factor, and MCP-1 [48]. So monocyte depletion may not only reduce interaction of macrophages with RPE cells, but also cause a negative cycle that exacerbates reduction of angiogenic factors, BMC recruitment, and ultimately $\mathrm{CNV}$ formation. We propose that finding ways to prevent contact between monocytes and RPE cells may lead to new techniques for inhibiting CNV.

Our findings showed that early reduction of monocyte infiltration into laser spot could reduce recruitment and incorporation of BMCs into experimental CNV, and SDF-1 expression in laser lesions. Together with the finding that contact between monocytes and RPE cells directly promoted SDF-1 expression in RPE cells in vitro, we postulate that monocytes/macrophages have a pivotal role in promoting vasculogenesis in CNV by enhancing SDF-1 expression. This provided a feasible mechanism for the function of monocytes in CNV. An understanding of the interactions between monocytes, local angiogenic factors, and RPE cells may constitute a critical platform for new therapeutic strategies for CNV.

Acknowledgments This work was supported by grants from the National Natural Science Foundation of China (No.30371516, 30672291). The project was sponsored partly by the equipment donation from the Alexander von Humboldt Foundation in Germany (to YS Wang, V-8151/02085).

\section{References}

1. Noël A, Jost M, Lambert V, Lecomte J, Rakic JM (2007) Antiangiogenic therapy of exudative age-related macular degeneration: current progress and emerging concepts. Trends Mol Med 13:345-352

2. Chappelow AV, Kaiser PK (2008) Neovascular age-related macular degeneration: potential therapies. Drugs 68:1029-1036

3. Nussenblatt RB, Ferris F 3rd (2007) Age-related macular degeneration and the immune response: implications for therapy. Am J Ophthalmol 144:618-626 
4. Coleman HR, Chan CC, Ferris FL 3rd, Chew EY (2008) Agerelated macular degeneration. Lancet 372:1835-1845

5. Patel M, Chan CC (2008) Immunopathological aspects of agerelated macular degeneration. Semin Immunopathol 30:97-110

6. Xu H, Chen M, Forrester JV (2009) Para-inflammation in the aging retina. Prog Retin Eye Res 28:348-368

7. Grossniklaus HE, Green WR (2004) Choroidal neovascularization. Am J Ophthalmol 137:496-503

8. Zou Y, Xu X, Chiou GC (2006) Effect of interleukin-1 blockers, CK112, and CK116 on rat experimental choroidal neovascularization in vivo and endothelial cell cultures in vitro. $\mathrm{J}$ Ocul Pharmacol Ther 22:19-25

9. Shi X, Semkova I, Müther PS, Dell S, Kociok N, Joussen AM (2006) Inhibition of TNF- $\alpha$ reduces laser-induced choroidal neovascularization. Exp Eye Res 83:1325-1334

10. Izumi-Nagai K, Nagai N, Ozawa Y, Mihara M, Ohsugi Y, Kurihara T, Koto T, Satofuka S, Inoue M, Tsubota K, Okano H, Oike Y, Ishida S (2007) Interleukin-6 receptor-mediated activation of signal transducer and activator of transcription-3 (STAT3) promotes choroidal neovascularization. Am J Pathol 170:2149-2158

11. Izumi-Nagai K, Nagai N, Ohgami K, Satofuka S, Ozawa Y, Tsubota K, Umezawa K, Ohno S, Oike Y, Ishida S (2007) Macular pigment lutein is antiinflammatory in preventing choroidal neovascularization. Arterioscler Thromb Vasc Biol 27:2555-2562

12. Sagara $N$, Kawaji $T$, Takano A, Inomata $Y$, Inatani $M$, Fukushima M, Tanihara H (2007) Effect of pitavastatin on experimental choroidal neovascularization in rats. Exp Eye Res 84:1074-1080

13. Tsutsumi C, Sonoda KH, Egashira K, Qiao H, Hisatomi T, Nakao S, Ishibashi M, Charo IF, Sakamoto T, Murata T, Ishibashi T (2003) The critical role of ocular infiltrating macrophages in the development of choroidal neovascularization. J Leukoc Biol 74:25-32

14. Espinosa-Heidmann DG, Suner IJ, Monroy D, Csaky KG, Cousins SW (2003) Macrophage depletion diminishes lesion size and severity in experimental choroidal neovascularization. Invest Ophthalmol Vis Sci 44:3586-3592

15. Sakurai E, Anand A, Ambati BK, van Rooijen N, Ambati J (2003) Macrophage depletion inhibits experimental choroidal neovascularization. Invest Ophthalmol Vis Sci 44:3578-3585

16. DG Espinosa, A Caicedo, EP Hernandez, SW Cousins (2003) Adult bone marrow derived progenitor cells contribute to choroidal neovascularization and modulate the severity. Invest Ophthalmol Vis Sci 44: E-Abstract 3936.

17. DG Espinosa, Caicedo, EP Hernandez, S Pereira, Y. Pina, KG Csaky, SW Cousins (2004) Aged bone marrow transfers agerelated pathology into young recipients in experimental choroidal neovascularization (CNV). Invest Ophthalmol Vis Sci 45: EAbstract 1853.

18. Sengupta N, Caballero S, Mames RN, Butler JM, Scott EW, Grant MB (2003) The role of adult bone marrow derived stem cells in choroidal neovascularization. Invest Ophthalmol Vis Sci 44:49084913

19. Sengupta N, Caballero S, Mames RN, Timmers AM, Saban D, Grant MB (2005) Preventing stem cell incorporation into choroidal neovascularization by targeting homing and attachment factors. Invest Ophthalmol Vis Sci 46:343-348

20. Apte RS, Richter J, Herndon J, Ferguson TA (2006) Macrophages inhibit neovascularization in a murine model of age-related macular degeneration. PloS Med 3:e310

21. Van Rooijen N, Sanders A (1994) Liposome mediated depletion of macrophages: Mechanism of action, preparation of liposomes and applications. J Immunol Meth 174:83-93

22. Zhao W, Wang YS, Hui YN, Zhu J, Zhang P, Li X, Dou GR (2008) Inhibition of proliferation, migration and tube formation of choroidal microvascular endothelial cells by targeting HIF-1alpha with short hairpin RNA-expressing plasmid DNA in human RPE cells in a coculture system. Graefes Arch Clin Exp Ophthalmol 246:1413-1422

23. Hou HY, Liang HL, Wang YS, Zhang ZX, Wang BR, Shi YY, Dong X, Cai Y (2010) A therapeutic strategy for choroidal neovascularization based on recruitment of mesenchymal stem cells to the sites of lesions. Mol Ther 18(10):1837-1845

24. Hou HY, Wang YS, Xu JF, Wang YC, Liu JP (2006) The dynamic conduct of bone marrow-derived cells in the choroidal neovascularization microenvironment. Curr Eye Res 31:1051-1061

25. Hou HY, Wang YS, Xu JF, Wang BR (2008) Nicotine promotes contribution of bone marrow-derived cells to experimental choroidal neovascularization in mice. Exp Eye Res 86:983-990

26. Wragg A, Mellad JA, Beltran LE, Konoplyannikov M, San H, Boozer S, Deans RJ, Mathur A, Lederman RJ, Kovacic JC, Boehm M (2008) VEGFR1/CXCR4-positive progenitor cells modulate local inflammation and augment tissue perfusion by a SDF-1-dependent mechanism. J Mol Med 86:1221-1232

27. de Almeida MC, Silva AC, Barral A, Barral Netto M (2000) A simple method for human peripheral blood monocyte isolation. Mem Inst Oswaldo Cruz 95:221-223

28. Yoshida A, Elner SG, Bian ZM, Kunkel SL, Lukacs NW, Elner VM (2001) Differential chemokine regulation by Th2 cytokines during human RPE-monocyte co-culture. Invest Ophthalmol Vis Sci 42:1631-1638

29. Bian ZM, Elner SG, Elner (2007) Thrombin-induced VEGF expression in human retinal pigment epithelial cells. Invest Ophthalmol Vis Sci 48:2738-2746

30. Moldovan NI (2002) Role of monocytes and macrophages in adult angiogenesis: A light at the tunnel's end. J Hematother Stem Cell Res 11:179-194

31. Kimura YN, Watari K, Fotovati A, Hosoi F, Yasumoto K, Izumi H, Kohno K, Umezawa K, Iguchi H, Shirouzu K, Takamori S, Kuwano M, Ono M (2007) Inflammatory stimuli from macrophages and cancer cells synergistically promote tumor growth and angiogenesis. Cancer Sci 98:2009-2018

32. Cursiefen C, Chen L, Borges LP, Jackson D, Cao J, Radziejewski C, D'Amore PA, Dana MR, Wiegand SJ (2004) Streilein JW (2004) VEGF-A stimulates lymphangiogenesis and hemangiogenesis in inflammatory neovascularization via macrophage recruitment. J Clin Invest 113:1040-1050

33. Sunderkotter C, Nikolic T, Dillon MJ, Van Rooijen N, Stehling M, Drevets DA, Leenen PJ (2004) Subpopulations of mouse blood monocyte differ in maturation stage and inflammation response. $\mathrm{J}$ Immunol 172:4410-4417

34. Apte RS, Richter J, Herndon J, Ferguson TA (2006) Macrophages inhibit neovascularization in a murine model of age-related macular degeneration. PloS Med 3(8):e310

35. Espinosa-Heidmann DG, Reinoso MA, Pina Y, Csaky KG, Caicedo A, Cousins SW (2005) Quantitative enumeration of vascular smooth muscle cells and endothelial cells derived from bone marrow precursors in experimental choroidal neovascularization. Exp Eye Res 80:369-378

36. Espinosa-Heidmann DG, Caicedo A, Hernandez EP, Csaky KG, Cousins SW (2003) Bone marrow-derived progenitor cells contribute to experimental choroidal neovascularization. Invest Ophthalmol Vis Sci 44:4914-4919

37. Butler JM, Guthrie SM, Koc M, Afzal A, Caballero S, Brooks HL, Mames RN, Segal MS, Grant MB, Scott EW (2005) SDF-1 is both necessary and sufficient to promote proliferative retinopathy. J Clin Invest 115:86-93

38. Jin DK, Shido K, Kopp H-G, Petit I, Shmelkov SV, Young LM, Hooper AT, Amano H, Avecilla ST, Heissig B, Hattori K, Zhang F, Hicklin DJ, Wu Y, Zhu Z, Dunn A, Salari H, Werb Z, Hackett NR, Crystal RG, Lyden D, Rafii S (2006) Cytokine-mediated deployment of SDF-1 induces revascularization through recruitment of CXCR4+ hemangiocytes. Nat Med 12:557-567 
39. Grunewald M, Avraham I, Dor Y, Bachar-Lustig E, Itin A, Jung S, Chimenti S, Landsman L, Abramovitch R, Keshet E (2006) VEGF-induced adult neovascularization: recruitment, retention, and role of accessory cells. Cell 124:175-189

40. Guerin E, Sheridan C, Assheton D, Kent D, Wong D, Grant M, Hiscott P (2008) SDF1-alpha is associated with VEGFR-2 in human choroidal neovascularisation. Microvasc Res 75:302-307

41. Holtkamp GM, Kijlstra A, Peek R, de Vos AF (2001) Retinal pigment epithelium-immune system interactions: cytokine production and cytokine-induced changes. Prog Retin Eye Res 20:29-48

42. Bian ZM, Elner SG, Yoshida A, Elner VM (2003) Human RPE-monocyte co-culture induces chemokine gene expression through activation of MAPK and NIK cascade. Exp Eye Res 76:573-583

43. Oh H, Takagi H, Takagi C, Suzuma K, Otani A, Ishida K, Matsumura M, Ogura Y, Honda Y (1999) The potential angiogenic role of macrophages in the formation of choroidal neovascular membranes. Invest Ophthalmol Vis Sci 40:18911898
44. Crane IJ, Wallace CA, McKillop-Smith S, Forrester JV (2000) CXCR4 receptor expression on human retinal pigment epithelial cells from the blood-retina barrier leads to chemokine secretion and migration in response to stromal cell-derived factor 1 . J Immunol 165:4372-4378

45. Hill WD, Hess DC, Martin-Studdard A, Carothers JJ, Zheng J, Hale D, Maeda M, Fagan SC, Carroll JE, Conway SJ (2004) SDF1 (CXCL12) is upregulated in the ischemic penumbra following stroke: association with bone marrow cell homing to injury. J Neuropathol Exp Neurol 63:84-96

46. Luft FC (2008) Mononuclear inflammatory cells and angiogenesis. J Mol Med 86:1193-1195

47. Takahashi K, Shimokado K, Yoshida M (2006) SDF-1-induced adhesion of monocytes to vascular endothelium is modulated by azelnidipine via protein kinase $\mathrm{C}$ inhibition. Eur $\mathrm{J}$ Pharmacol 552:162-169

48. Kinnaird T, Stabile E, Burnett MS, Shou M, Lee CW, Barr S, Fuchs S, Epstein SE (2004) Local delivery of marrow-derived stromal cells augments collateral perfusion through paracrine mechanisms. Circulation 109:1543-1549 